\title{
Skolelederes organisering av Lesson Study-arbeid
}

Forfatter: Nini Ebeltoft $(P h D)$

ORCID: http://orcid/0000-0002-9840-0664

Universitetet i Oslo

Artikkelen og deler av denne må ikke siteres fra eller (gjen)brukes uten at det refereres til forfatter, tittel og den opprinnelige publiseringen $i$ Norsk pedagogisk tidsskrift, 01/2018 s. 72-82, med

DOI: 10.18261/issn.1504-2987-2018-01-08

\begin{abstract}
English)
Historically, Lesson Study (LS) has been considered a method for developing competencebased approaches to teaching and learning as part of elementary and secondary school practices. This research article is based on qualitative data and the study of implementations of LS in lower secondary schools, where school leadership is analysed in relation to LS work and the use of organisational resources. Emphasis is put on the work of organising, interpreting and implementing LS. Through analysis of empirical data from interviews and observations, two perspectives are discussed which illustrate different styles of leadership with associated perspectives, strategies and forms of organisation. Different, yet complementary perspectives are described that provide insight into school leadership and a multitude of organisational aspects, forms of collaboration and professional development.
\end{abstract}

Keywords: School Leadership, Lesson Study, School Development, Competency-Based Approach, Lower Secondary Schools, Work Organisation \& Program Implementation

\section{Sammendrag (Norsk)}

Historisk sett har Lesson Study (LS) vært en måte å drive skolebasert kompetanseutvikling på. Artikkelen viser hvordan fors $\varnothing \mathrm{k}$ på implementering av LS på et utvalg skoler påvirkes av skolelederes bruk av retoriske og organisatoriske redskaper og ressurser. 
Forskningsspørsmålet setter fokus på skoleledernes syn på og organisering av arbeidet ved utforsking, iverksetting og forankring av LS. Med utgangspunkt i et empirisk materiale diskuteres to perspektiver som anskueliggjør ulike ledelsesstrategier og former for organisering og ressursbruk. Det gir innsikt i hvordan aspekter som tid, samarbeidsfora og fagrettede prosesser påvirker deltakernes interesser og utførelse av arbeidet.

Emneord: Skoleledelse, utdanningsledelse, ledelsesstrategier, Lesson Study, skoleutvikling, skolebasert kompetanseheving, programimplementering, ungdomsskole \& empirisk forskning.

\section{Innledning}

Artikkelen utforsker Lesson Study-arbeid med utgangspunkt i et utvalg skolelederes organisering av arbeidet på skolene de ledet. Forskningsspørsmål for studien har vært: Hva kjennetegner skoleledelsens syn på og organisering av Lesson Study-arbeidet? Lesson Study (LS) er en metode for profesjonalisering av forhold knyttet til læring og undervisning. Den omtales gjerne som en systemisk tilnærming til skoleutvikling der lærere samarbeider om å utforske og forbedre undervisningen i fag de har ansvar for. Historisk sett har LS vært en måte å drive skolebasert kompetanseutvikling på i form av lokale, innenfra- og ut-prosesser som begrepsmessig er forankret i metodens japanske opphav. Artikkelen skisserer to ledelsesperspektiver der uttalelser fra skoleledere analyseres i relasjon til ressursbruk, organisering og iverksetting av LS.

\section{Teoretisk forankring og forskningsperspektiv}

I en internasjonal oversiktsartikkel konkluderer Xu og Pedders med at "storparten av forskning på LS utgjør mindre studier som benytter kvalitative, eksplorative og induktive metoder som har hjulpet forskere i å studere ulike former for LS tilrettelagt for bruk i ulike sammenhenger" $\left(2015\right.$, s. 49-50) ${ }^{1}$. Forfatterne etterlyser samtidig mer forskning på ledelse, organisering og mikropolitiske prosesser som påvirker LS-arbeidet, og referer til Robinson og Leikin (2012) som bekrefter viktigheten av å undersøke LS-implementering i ulike land og

\footnotetext{
${ }^{1}$ Sitatet er oversatt fra engelsk av forfatteren. Andre systematiske oversikter, f.eks Cheung \& Wong (2014) gir et liknende bilde, men uten at ledelsesperspektiver er med.
} 
ved skoler med ulik praksis og organisasjonskultur. Behovet for empiriske studier av LS og av skoleledelse presiseres også av andre forskere (se f.eks. Lewis, Perry \& Murrata 2006; Spillane 2009; Hope \& Grimsæth 2016; Wilkinson \& Bristol 2018). Sett under ett er det forsket mye på skoleledelse, men svært lite i relasjon til LS-arbeid og studier som trekker inn ulike kontekster og nivåer. Av unntakene er Akiba og Wilkinsons (2016) studie som viser hvordan utdanningsmyndigheter i Florida igangsatte metodeimplementering i stor skala da LS ble ansett som et nyttig redskap for skoleutvikling og profesjonalisering, og der konsulentfirmaer og statsansatte rådgivere veiledet skolene i arbeidet. Saito \& Sato (2012) har i litt mindre målestokk vist hvordan LS fungerte som instrument for skolereform ved hvordan ledelsen ved en japansk ungdomsskole (chūgakkō) iverksatte LS i omstillingsprosesser der hele skolen var involvert. I Dudleys (2015) forskning på grunnskolerektorers arbeid med LS står derimot lærernes læring og utøvelse av autonomi sentralt (se også Chenault 2017). I nordisk sammenheng utgjør ledelsesperspektiver ofte en mindre del av større studier, som hos Olsen og Wølners (2017) der fokus er LS i relasjon til lærernes læring og kompleksiteten i utvikling av fagkompetanser (se også Munthe, Helgevold \& Bjuland 2015; Hallås \& Grimsæth 2016).

Empirisk forskning som undersøker skoleledelsens syn på og organisering av LS er derfor tiltrengt, og den foreliggende studien er et bidrag i slikt henseende. En leders perspektiv er gjerne et resultat av erfaringer og kunnskaper som virker strukturerende for beslutninger og iverksettingsstrategier (Jacobsen \& Thorsvik 2014; Northouse 2016). Men også av spenninger og påvirkninger fra ytre og indre krefter med følger for de orienteringer og organisasjons- og relasjonsbyggingsprosesser ledelsen fokuserer på, slik denne studien viser (jf. Møller \& Ottesen 2011; Courtney, McGinity \& Gunter 2018). Påvirkningene diskuteres her ut fra to caser som synliggjør ledelsens erfaringer med og vurderinger av LS i arbeid med skolebasert kompetanseutvikling. Historisk sett er det interessant da det siden LS ble importert til USA fra Japan på 1990-tallet har vært vanlig å fremstille metoden som et redskap for lokal skoleutvikling, oftest med mål om å fremme elevers og læreres læring (Takahashi 2000; Hart, Alston \& Murata 2011; Ronda 2013). LS har de siste tiår fått et kraftig oppsving internasjonalt der utbredelsen har frembrakt nye allianser, interessenter og rådgivningstjenester. Trolig en effekt av hvordan en fra utdanningspolitisk hold har knyttet LS til reformer og satsingsområder, og hvordan ulike varianter av LS har vokst frem lokalt. Med empiri som utgangspunkt vil LS derfor både belyses fra et innen- og et utenfra-perspektiv som 
viser forbindelser, ledelses- og organisasjonsformer slik de uttrykkes gjennom ledernes beskrivelser av arbeidet. For, som Irgens (2016) påpeker, det er i møtet mellom ytre og indre krefter, ideer og realiteter skolens praksis tar form. Argumentet er at studier som benytter en bifokal optikk med beskrivelser av ulike perspektiver og interesser, vil synliggjøre komplekse og motsetningsfylte forhold ved sammenstilling av horisontale og vertikale linjer og strukturer. Fra et innenfra-perspektiv unders $\varnothing$ ker artikkelen derfor hvordan ledelsesformer og profesjonsrettede interesser og forhold påvirker arbeidet med iverksetting. Tyngdepunktet er kollegiet og organiseringen av ressurser. Et utenfra- perspektiv åpner for i hvilken grad lederne opplever at overordnede styringssignaler og interessekoalisjoner er avgjørende og virker inn på arbeidet. Undersøkelsen drar nytte av Hadfield \& Joplings (2016) studie av hvordan LS og profesjonalisering gjensidig konstrueres og rekonfigureres ved kollaborativt arbeid innad på skolene og utad i relasjon til skoleeier og politisk-administrativt apparat. I studiet av implementerings- og utviklingsarbeid bygger artikkelen på Fullans modell av ideer og ordninger som settes ut i praksis der disse er nye for de som iverksetter dem, i denne sammenheng med vekt på initieringsfasen (Fullan 2007, 2017a).

\section{Forskningsmetodisk tilnærming}

Unders $\varnothing$ kelsens kvalitative forskningsdesign bygger på semistrukturerte intervjuer av 10 personer i stillinger som rektorer, assisterende rektorer og undervisningsinspektører, samt observasjoner av LS-arbeid i klasserom og på plenumsøkter ved 6 skoler på Østlandet. Intervjuene er individuelle dybdeintervjuer med 1-2 timers varighet foretatt på skolene i november og desember 2015 med dialogisk validering og oppfølgingsspørsmål i 2016 og 2017 (Malterud 2017). Foruten observasjoner og intervjuer bygger studien på 90 skolebes $\varnothing \mathrm{k}$ ved 18 skoler og logg- og notatføring fra plenumsmøter, samt separate møter med skoleledelsen. I tillegg kommer tilstedeværelse på LS-tilknyttede seminarer og konferanser som bakgrunn for å forstå skoleledelsens preferanser, referanser og inspirasjonskilder. Studiet omfatter også analyser av lokale, regionale og nasjonale strategi- og plandokumenter som ledelsen forholdt seg til i arbeidet, samt forskningslitteratur de refererte til. I alt 6 skoler ble tilfeldig valgt fra 18 skoler, der det fra de 6 med hensikt ble trukket ut materiale fra to skoler (skole 1 og 2) med divergerende trekk som eksemplifiserer ulike perspektiv og former for ledelse. Dette tydeliggjøres i artikkelen ved to caser med intervjudata fra skole 1 representert ved rektor (mann, ca. 50 år) og en undervisningsinspektør (mann ca. 35 år), samt fra skole 2 ved rektor (kvinne ca. 55 år) og en undervisningsinspektør (mann ca. 35 år). Av plasshensyn begrenses på denne måten intervjudata. Ved skole 1 med 1.-10.-årstrinn, var kun 8.-10.-trinn 
med i studien som på intervjutidspunktet talte om lag 200 elever og 20 lærere. Skole 2 var en ungdomsskole der 8.-10.-trinn hadde ca. 200 elever og 20 lærere. Skolene deltok i den nasjonale satsingen Ungdomstrinn i utvikling (UiU) som foregikk i perioden 2013-2016.

De transkriberte intervjuene og annet empirisk materiale ble innledningsvis sammenstilt, sammenliknet, tolket og vurdert gjennom kartlegging av trekk og tendenser i et toforskersamarbeid og i diskusjoner med forskerkolleger. Analysen av likheter og forskjeller er basert på dette. Ekstern forsker ble trukket inn for reliabilitetstesting. I tolkning og analyse er det også vurdert hvorvidt kjennskap til intervjuobjektene kan ha påvirket svarene (Kvale, Brinkmann, Anderssen \& Rygge 2009). I tekstmaterialet er deltakerne av analytiske og forskningsetiske grunner anonymisert og noen identitetsmarkører endret uten å flytte data ut av sin opprinnelige kontekst. Antallet skoler og intervjuer utgjør en begrensning og studien kan på ingen måte sies å være representativ for skoler involvert i UiU. Samtidig tydeliggjør studien viktige trekk og tendenser som bidrag til kunnskap om ledelse og organisering av LSarbeid. Studien ble i 2015 og 2016 rapportert til NDS og oppfyller forskningsetiske betingelser som informert samtykke og frivillig deltakelse. Litteraturs $\varnothing \mathrm{k}$ er foretatt ved kombinerte og kontrollerte emnes $ø$ tilknyttet problemstilling og forskningstema i seks elektroniske databaser, samt i nordiske og internasjonale oppslagsverk, tidsskrifter og reviewtidsskrifter.

\section{Historisk og begrepsmessig forankring}

LS-arbeid kan spores tilbake til japanske skolers bruk av metoden på 1800-tallet. Fra 1960tallet har beskrivelser av LS, på japansk kalt jugyō kenkyū, vært knyttet til skolebasert kompetanseutvikling og begrepet kōnai kensh $\bar{u}$ som signaliserer et innenfra og ut-perspektiv på praksis (Makinae 2010; Arani, Fukaya \& Lassegard 2010). ${ }^{2}$ Kvaliteten på arbeidet betraktes som avhengig av interesse, innsats og ansvarstaking blant lærerne og skoleledelsens evne til å forankre LS gjennom faglig samarbeid og samhold lokalt (Fernandez \& Yoshida 2004).

\footnotetext{
${ }^{2}$ I begrepet kōnai kenshū (校内研修) oversettes kōnai gjerne til “innenfor" skolen og kenshū til "trening”.
} 


\section{Lesson Study som skolebasert og kompetansebyggende redskap}

LS-arbeid utføres i avgrensede tidsrom (sykluser) der 3-6 lærere samarbeider om å utforske egen undervisningspraksis. Hensikten er å utvikle ny profesjonskunnskap i arbeid med opplegg, materialer og metoder som knytter fagkunnskap til organisering og læring (se Lewis 2002; Wiburg \& Brown 2007; Cerbin 2011). Felles planlegning av 1-3 undervisningstimer med tilhørende målformuleringer og forskningsspørsmål gir retning til undervisning, datainnsamling og diskusjon. Lærerne tester opplegget og gjennomfører undervisningstimen ved at en av lærere underviser mens de andre samler data gjennom observasjon. I påfølgende gruppearbeid analyser og evaluerer de resultater før opplegget eventuelt revideres og prøves ut på nytt. Det spesielle er metodens forskningsmetodikk og undersøkelseslogikk med bruk av forskningsspørsmål og faglitteratur. Metodebruken er også avhengig av lærernes kompetanse, erfaringer og kjennskap til elevenes utvikling, arbeidsinnsats og resultater.

\section{Kontrasterende perspektiver på ledelse og organisering}

I de to casene under presenteres i første rekke uttalelser fra rektorene ved skole 1 og $2 .{ }^{3}$ Case A viser at arbeidet med LS som et utviklings- og kompetansehevende tiltak gikk tregt tross satsing på fag, frivillighet og engasjement. Case B viser at skolens arbeid var godt $\mathrm{i}$ gang, men avdekker organisatoriske utfordringer i det å skape tid og rom for samarbeid og fagrettede utviklingsprosesser. Da arbeidsorganiseringen ved skole 2 var mer omfattende enn på skole 1, rommer case B flere empiriske data.

\section{Case A, skole 1}

Skolens ledelse besto av rektor, assisterende rektor og en undervisningsinspektør. I samråd med skoleeier avgjorde ledelsen at skolen i en toårsperiode skulle satse på LS og kompetanseheving i matematikk med mål om å bedre elevenes forståelse for og resultater i faget. Rektor nedsatte en plangruppe for arbeidet som foruten ledelsen inkluderte to ressurslærere. Han vekta hvordan koblingen mellom LS og UiU styrket kontakten med skoleeier og ga ledelsen den legitimitet den trengte for å løfte frem og samordne skolens utviklings- og kompetansehevingstiltak. Utdanningspolitiske ideer introdusert i Kunnskapsløftet (LK06), stortingsmeldinger og utredninger om styrking av fagkompetanse og

\footnotetext{
${ }^{3}$ Alle uttalelser i anførselstegn er fra rektorene hvis ikke annet er oppgitt.
} 
profesjonsutvikling ble med dette videreført. ${ }^{4}$ På spørsmål om målet med LS-arbeidet kom svaret raskt:

Målet er å utvikle kunnskap og ferdigheter som har betydning for lærernes daglige arbeid med elever og det å skape et større profesjonsfellesskap ... Et delmål er å se sammenhenger mellom lærernes faglige og pedagogiske valg, og elevenes læring ... [for] å utvikle metoder som fremmer elevenes læring ... Det siste var fokus i kollegaveiledningen også, og tema i samtaler mellom lærerne.

LS ses her som et redskap for profesjonalisering og undersøkelse av forbindelser mellom lærernes arbeid og elevers læring. Rektoren understreket at det har tatt veldig lang tid før en fra utdanningspolitisk hold har oppfordret til kvalitativ kartlegging av hvorvidt elevenes ferdigheter samsvarer med kompetansemålene i LK06, med forslag til verktøy og metoder for dette. Ved reformbasert utvikling og implementering mente han det gjaldt “å snevre inn og avgrense" en satsing og innhente bistand fra "eksterne veiledere og eksperter". Han støttet stats-initierte undersøker og forbedringsstrategier for læring og faglige resultater som grunnlag for videreutvikling av skolens pedagogiske og fagdidaktiske kompetanse. Satsingen på LS bygget på dette og ideer om å bedre lærernes muligheter for å "utforske ... og ha et kritisk blikk på eget arbeid" og kartlegge om de "stiller ulike forventninger til sterke og svake elever i relasjon til deres kognitive potensial”. Inspektøren påpekte at kartlegging av "matematikkundervisningen viste at vi [skolen] ikke klarte å heve resultatene i matematikk, særlig med hensyn til de svake elevene". LS skulle derfor brukes som metodisk instrument for utvikling og profesjonalisering av forholdet mellom undervisning og elevarbeid. "Matematikk er et veldig fint fag å drive Lesson Study i, fordi det er så pass avgrensede temaer du kan forske på, f.eks. algebra" ... "Matteseksjonen arbeider også veldig tett, reflekterer, lager nye opplegg, osv., men dette [med LS] er ikke satt helt i system” (inspektør).

Mindre deler av lærerkollegiet hadde et års tid arbeidet med kollegaveiledning der de parvis observerte hverandres undervisning der "fokus var på læreren, observasjonen, og det å gjøre hverandre bedre på ulike områder”. Etter blandete erfaringer med dette ønsket ledelsen å “flytte fokus fra læreren til eleven” fordi "Lesson Study er en bedre måte ... å utforske hva det

\footnotetext{
${ }^{4}$ Rektor nevnte bl.a. regjeringens strategidokument Laererlфftet (2014), St.meld. 30 (2007 - 2008) og St.meld. 31 (2007-2008), samt Utdanningsdirektoratets nettsider med informasjon om Lesson Study.
} 
egentlig er som fungerer for ulike elever i praksis". Rektor vektla hvordan LS krever intensivt lærersamarbeid og et arbeidsfellesskap det kan være ressurskrevende å organisere. Det var uansett avgjørende "å holde trykket oppe" og fortsette "ut fra frivillighet og med de som viste engasjement". Arbeid med innledende tiltak, organisatoriske løsninger og sikring av ressurser og møtetid gikk tregt tross ambisjonen om "å skape utvikling, engasjere ... og holde fokuset uten å forplikte alle”. Åtte måneder etter fastsatt oppstart hadde LS-arbeidet fremdeles ikke kommet ordentlig i gang.

\section{Case B, skole 2}

Skolens ledelse besto av rektor og en undervisningsinspektør. LS-arbeidet ble igangsatt ut fra en gruppe "læreres ønske om å lage og planlegge undervisningsopplegg sammen, slik som i Lesson Study”. Hensikten var «å komme inn og se på [observere] oppleggene til hverandre” (inspektør). Prosjektgruppen med ansvar for planlegning og oppføling av LS bestod av ledelsen og to ressurslærere. Metoden var også her koblet til arbeid med UiU, der forbedring av elevenes kompetanse i matematikk sto sentralt. Innsats og resultater av arbeidet ble evaluert på fellessamlinger. Organisatorisk endringsarbeid som innbefattet lærernes undervisningspraksis ble ifølge rektoren diskutert og definert gjennom felles planlegging. Rektor gjorde et poeng av at skolen tok seg tid til arbeidet der forstyrrende faktorer ble ryddet av veien. Satsing på LS ble avgjort etter skriftlig avstemning i lærerkollegiet, etterfulgt av et heldagsseminar viet metoden. Rektor ønsket å trekke så mange lærere som mulig med i arbeidet, derfor var en av seminarforberedelsene å studere et hefte om LS utarbeidet av ledelsen. Seminaret skulle gi lærerne mulighet til å gå i dybden og planlegge LS-arbeidet i fagseksjonene: "Det ble en form for dybdelæring fordi Lesson Study er en metode lærerne må få litt under huden ... vi trengte en gjennomgang av essensen og hva vi ønsket ut av dette og ... fagsamarbeidet". I likhet med skole 1 hadde lærerkollegiet arbeidet med kollegaveiledning, noe rektor hadde inntrykk av banet vei for LS-arbeidet. LS ble slik en del av skolens kontinuerlige satsing på fag- og kompetanseutvikling:

Egentlig startet vi lenge før seminaret ved å prøve ut kollegaveiledning som del av arbeidet med UiUsatsingen, men så ønsket vi mer fokus på elevenes læring, ikke nødvendigvis på kollegaen. Vi ønsket å bygge opp lærernes kompetanse og ... la opp til at personalet selv skulle være med å vurdere hva de ønsket av kollegaveiledningen og Lesson Study ved å drøfte dette på trinn, og hva de ønsket å gå i dybden på, prøve ut, osv. Dette for å unngå top-down-styring. Det viste seg at størstedelen av personalet ønsket Lesson Study og det å ha fokus på elevenes læring ... og på det å forske, for uansett pedagogisk 
utviklingsområde kan Lesson Study som metode brukes som del av det å utvikle noe nytt. Om det er fagseksjonen som skal utvikle noe nytt eller trinnet, så skal jo opplegg prøves ut og da kan en gå inn å forske på noe av dette ved å sette fokus på elevenes læring - for det er der vi skal være. Ved å jobbe med Lesson Study får lærerne en holdning og en forståelse for det å forske på læring ... både når de felles utvikler noe, men også når det gjelder verktøy for på sikt å forske litt på egen undervisning og hvordan observere.

Medvirkning og utprøving foregikk altså på basis av felles drøfting og identifisering av ønsker og behov. Inspektøren mente erfaringer fra kollegaveiledningen fikk flere engasjert $\mathrm{i}$ prosessen: "Siden vi har vært så godt i gang med kollegaveiledning, ble dette [LS] opplevd som en naturlig forlengelse av det ... og endelig å få jobbe i dybden. Ressurslærerne har vært veldig på siden vi startet”. Lærerne tok metoden i bruk ved å utforske forbindelser mellom faginnhold, opplegg og læringsbehov. Rektor så det som ledelsens oppgave å tilrettelegge for og "synliggjøre dette ... [fordi] kanskje de ønsker å endre praksis og hvordan de argumenterer for hvilken praksis de velger” ... så “vi må gå inn, verdsette og løfte opp, synliggjøre”. Samtidig understreket hun at det var en organisatorisk utfordring å få avsatt nok ressurser og “dybdetid” til arbeid på trinn og i fagseksjoner, og utdyper:

Dybdetid til noe vi vil jobbe med og satse på ved at lærerne får følelsen av å kunne gå i dybden [faglig og metodisk] uten alt det andre som henger rundt ørene på dem. Det tror jeg er helt vesentlig for å få lærerne med på utviklingsarbeid ... og for at fagseksjonen kan jobbe i dybden - f.eks. i matematikk og spørre: Hvordan vil elevene lære best om algebra? - da kan de lage gode algebra-opplegg fordi dybdelæring og det å kunne gå i dybden fremover er vesentlig for godt fagseksjonsarbeid og endelig få satt fokus på gode opplegg ... Før seminaret hadde jeg en samtale med tillitsvalgt fordi det [LS] har mye med tidsbruk å gjøre, og da avklarte vi f.eks. at ekstratiden fra seminaret skulle verdsettes som tidsbruk da vi prøvde ut [LS] i vanlige, ordinære timer. Alle som underviste eller observerte fikk det anerkjent som samarbeidstidsbruk som kunne avspaseres senere. I tillegg var det åpent for at de kunne få vikar til egne timer. Fagforeningen var helt med på denne formen for tidsbruk.

Sitatet viser hvordan ledelsen anga rammebetingelser og sikret tid til utvikling og fordypning. “Alle synes det var utrolig godt å kunne få sitte og planlegge noe sånt - planlegge en Lesson Study-time sammen og få jobbe med faget [sitt] ... Det er jo et evig savn at en ikke får nok samarbeidstimer i faget” (inspektør). Organiseringen fordret ifølge inspektøren mye planlegning og møtevirksomhet, men la til at rektors oppmuntringer og oppfordring til innsats i team og på trinn var utslagsgivende. Overveielser, meningsutveksling og felles 
definisjonsarbeid for å enes om hva LS-arbeidet skulle være var en del av dette, her tydeliggjort av rektor:

\begin{abstract}
[Å] få denne begrepsforståelsen sammen i kollegiet er viktig. Vi har vår første utprøving av dette [LS] og det er faktisk mer enn nok at de prøver ut observasjonsskjemaet sammen og spisser til ting [da] de sammen har laget dette felles opplegget. Det er jo ut fra planleggingstid de skal gjennomføre og evaluere når de skal ut igjen [i neste syklus]. Så vi har åpnet opp alle samarbeidsmøtene i en periode på en måned. Det vil si at vi ikke har fellestid på en måned, fordi all tid skal være til lærersamarbeid om Lesson Study, evt. at de tar det på trinn ... [Det er] måten vi tenker, jobber sammen på, måten [vi] tar opp ting på sammen, prøver ut ting sammen, reflekterer sammen, og spisser til og spør: Hva ønsker vi å finne ut av sammen? Men også måten det blir styrt på, prioriteringer, osv.
\end{abstract}

Den nitide organiseringen og de kollektive og kompetansebyggende prosessene ga retning til arbeidet for systematisk iverksetting av LS basert på fellesvedtakene. Det gjaldt å trekke medarbeiderne med i beslutningsprosessen for slik å bruke kompetansen og potensialet i organisasjonen. Prioriteringen syntes avgjørende for hvordan lærerne drev arbeidet fremover. Det var "helt vesentlig" fordi "de [lærerne] skal organisere, lage [opplegg], planlegge og observere sammen. Det å sette av tid til planlegning har vært nøkkelen her”. Rektor etterlyste samtidig skoleeiers støtte og interesse for arbeidet, men innså at det forsvant blant andre viktige saker på agendaen, som kommunalstrategiske satsinger og kommunesammenslåing: "Skoleeier kunne bidratt med mye bredere støtte ... og fulgt [skolens] utvikling, for Lesson Study er en del av dette, hvordan jobbe kollektivt, hvordan utvikle organisasjonen".

\title{
Videre analyse og diskusjon
}

Ulike trekk og tendenser ved ledelsens syn på og organisering av LS vil i det videre diskuteres ut fra casene. Case $\mathrm{B}$ viser tydelige tegn på kompetanseutvikling og kapasitetsbygging innad på skolen gjennom ledelsens ambisiøse satsing på samarbeid og kollektiv arbeidsorganisering, mens forbindelsen utad, til skoleeier, fremstår som svak. I stedet for å starte med en mindre gruppe frivillige lærere (som skole 1), organiserte ledelsen fellessamlinger og samarbeidsordninger som trakk samtlige lærere med. De sikret ressurser og etablerte rammer, strukturer og støttesystemer for medvirkning og arbeids- og ansvarsfordeling som høynet forventningene og ga form til felles organisering og kommunikasjon. En demokratisk og godt koordinert arbeidsledelse som ut fra teorier om distribuert ledelse vil kunne karakteriseres som deltakende, inkluderende og pedagogisk (Leithwood, Mascall \& Strauss 2009; Robinson, 
Hohepa \& Lloyd 2009) med utvikling av nye samarbeidsmønstre internt (Spillane 2006). I lys av mer tradisjonelle og individorienterte teorier om skoleledelse vil rektors engasjement og arbeid med å motivere og inspirere, samt lærernes tillit og tiltro til organiseringen, kunne assosieres med termen transformasjonsledelse (Leithwood \& Jantzi 2005; Northouse \& Lee 2016). Det kan derfor være snakk om en mer sammensatt ledelsesform (Gronn 2009). Motivet for gjennomføring av transformative prosesser var profesjons- og organisasjonsutvikling, ikke aggregering av fagresultater (Gunter 2016). Ledelsens satsing på kollektiv mobilisering og utprøving gjennom “dybdetid” kan med Fullan (2017b) også karakteriseres som en type dybdeledelse. Ledelsens bruk av begrepet "dybdelæring” speiler trolig teori og retorikk fra utdanningspolitisk hold (f. eks. NOU 2014:7 og NOU 2015:8), men i dette tilfellet hadde begrepsbruken konkrete og kontekstuelle betydninger med forankring i diskusjoner og utprøving av praktisk og prinsipiell art.

En annen tendens viser seg i case A ved hvordan forbindelser utad til reformpolitiske ideer, styringsdokumenter og skoleeier preget ledelsens syn på fagarbeidet som samtidig var svakt koblet til LS-arbeid ved kollektive strukturer og kompetansebygging innad. En ledelsesform preget av lojalitet og lydhørhet for signaler, krav og ansvarsstyring utenfra der utdanningsmyndighetene tilrår å ta "ansvar for å samarbeide" (Gunter 2012, s. 58). Det gjaldt “å holde trykket oppe”, men trykket syntes mest å utgjøre et retorisk trykk som ikke virket innad i nevneverdig grad, for lite skjedde med hensyn til arbeidsorganisering og ansvarsfordeling blant lærerne. Samtidig skal en ikke se bort fra at rektors posisjon kan ha styrket skolens status utad, mens den til samme tid skjermet lærernes praksis fra påtrengende endringsideer og oppskrifter utenfra (jf. Christensen, Egeberg, Lægreid, Roness \& Røvik 2017; Gunter 2018). Forbindelseslinjene mellom skolens ledelse og skoleeier var virksomme, og i uformelle samtaler med lærerne ga skolen inntrykk av å ha et godt arbeidsmiljø. Rektors posisjonering mellom politikk og personale kan i så fall ses som en balansegang der det å drive ledelse i et spenningsfelt (Abrahamsen 2017) kan relateres til hvordan LS fra politiskadministrativt hold ble koblet til UiU og promotert på Utdanningsdirektoratets nettsteder, i strategidokumenter og på regionale skoleledersamlinger. Midtstillingen og balanseøvelsen kan med andre ord være en virkning av myndighetenes mangefasetterte og forventningsbaserte styringsform (jf. Elmore 2004).

I case B forklarer rektor hvordan ledelsen ville unngå "top-down-styring” ved å satse på kollektiv deltakelse og autonomi iverksatt gjennom medvirkningsformer som drøfting og 
evaluering. Arbeidet ble gitt prioritet ved at forankring og videreutvikling uforstyrret kunne skje innenfra. Lærerne forpliktet seg samtidig til metodeutprøving innen fellesdefinerte rammer. Tid, fora og studiearbeid utgjorde organisatoriske ressurser som ga styrke til kollektiv ansvarstaking og arbeidsinnsats. Gjennom utprøving og modifisering utviklet skolen en særegen, lokal variant av LS. Komparativt og med hensyn til å lede arbeidsorganisering kan det ha spilt en rolle at skole 2 var mindre enn skole 1. Når det gjaldt lærernes bruk av fagog forskningslitteratur på skolene ble dette i liten grad ble trukket inn, og mangelen på erfaring med forskningsbaserte metoder gjorde arbeidet tidkrevende (jf. Bjuland \& Mosvold 2015; Akiba \& Wilkinson 2016).

\section{Oppsummering og konklusjon}

I analysen av ulike ledelsesperspektiver er det pekt på to hovedtrekk ved skoleledernes syn på og organisering av LS-arbeidet. Det ene ved hvordan en gjennom demokratiske ledelses- og medvirkningsformer styrket de organisatoriske forbindelsene innad, slik at LS-arbeid og utforskning av undervisningen lot seg gjennomføre. En tilnærming som historisk sett er i tråd med annen fremstilling av LS. Det andre identifiserer en tendens i hvordan et endringsorientert lederskap ryddet vei for utdanningspolitisk reformarbeid initiert av drivkrefter utenfra, men der en tross fokus på frivillighet og profesjonsutvikling i liten grad utviklet tiltak og organisasjonsarbeid innad. I sum ulike ledelsesorienteringer, arbeidsorganiseringer og alliansebyggingsprosesser hvis bestrebelser enten ikke nådde helt inn til lærerne eller helt ut til skoleeier. Perspektivene avdekker slik både indrestyrte prosesser og ytrestyrte forhold.

\section{Referanser}

Abrahamsen, Hedvig (2017). Redesigning the role of deputy heads in Norwegian schools tensions between control and autonomy? International Journal of Leadership in Education, 1-17. DOI: 10.1080/13603124.2017.1294265

Akiba, Motoko \& Wilkinson, Bryan (2016). Adopting an international innovation for teacher professional development State and district approaches to lesson study in Florida. Journal of Teacher Education, 67(1), 74-93. DOI: 10.1177/0022487115593603 
Arani, Mohammad R. S., Fukaya, Keisuke, \& Lassegard, James P. (2010). "Lesson Study" as Professional Culture in Japanese Schools: An Historical Perspective on Elementary Classroom Practices. Nichibunken Japan Review, 22, 171-200.

Bjuland, Raymond \& Mosvold, Reidar (2015). Lesson study in teacher education: learning from a challenging case. Teaching and Teacher Education, 52, 83-90. DOI: $10.1016 /$ j.tate.2015.09.005

Cerbin, Bill (2011). Lesson Study: Using Classroom Inquiry to Improve Teaching Learning in Higher Education. Virginia: Stylus Publishing LLC.

Chenault, Krystel H. (2017). Building Collaborative Pedagogy: Lesson Study in Higher Education. College Quarterly, 20 (1).

Christensen, Tom, Egeberg, Morten, Lægreid, Per, Roness, Paul G., Røvik, Kjell Arne (2017). Organisasjonsteori for offentlig sektor ( $3^{\text {rd }}$ edition) Oslo: Universitetsforlaget.

Courtney, Steven J., McGinity, Ruth \& Gunter, Helen M. (Ed.) (2018). Educational Leadership: Theorising Professional Practice in Neoliberal Times. New York: Routledge.

Dudley, Peter (2015). Lesson Study: Professional learning for our time. New York: Routledge.

Elmore, Roger (2004). School reform from the inside out. Policy, practice, and performance. Cambridge, MA: Harvard University Press.

Fernandez, Clea, \& Yoshida, Makoto (2004). Lesson study: A Japanese approach to improving mathematics teaching and learning. New Jersey: Lawrence Erlbaum.

Fullan, Michael (2007). The new meaning of educational change ( $4^{\text {th }}$ edition). New York: Teacher College Press.

Fullan, Michael (2017). Ledelse som setter spor. Oslo: Cappelen Damm Akademisk.

Gronn, Peter (2009). Leadership Configurations. Leadership, 5 (3). DOI: 10.1177/1742715009337770

Gunter, Helen M. (2012). Leadership and the Reform of Education. Bristol: The Policy Press.

Gunter, Helen M. (2016). An intellectual history of school leadership practice and research. London: Bloomsbury Publishing. 
Hadfield, Mark \& Jopling, Michael (2016). Problematizing lesson study and its impacts: Studying a highly contextualised approach to professional learning. Teaching and Teacher Education, 60, 203-214. DOI: 10.1016/j.tate.2016.08.001

Hart, Lynn C., Alston, Alice S. \& Murata, Aki (Ed.) (2011). Lesson Study Research and Practice in Mathematics Education: Learning Together, New York: Springer.

Hallås, Bjørg Oddrun \& Grimsæth, Gerd (Ed.) (2016). Lesson Study i en nordisk kontekst. Oslo: Gyldendal.

Hope, Christine \& Grimsæth, Gerd (2016). Lesson study i en nasjonal satsing for bedre klasseledelse. I: B. Hallås \& G. Grimsæth (Ed.) Lesson Study i en nordisk kontekst. Oslo: Gyldendal.

Irgens, Eirik J. (2016). Skolen: organisasjon og ledelse, kunnskap og laering. Bergen: Fagbokforlaget.

Jacobsen, Dag Ingvar \& Thorsvik, Jan (2014). Hvordan organisasjoner fungerer (4th edition). Bergen: Fagbokforlaget.

Kvale, Steinar, Brinkmann, Svend, Anderssen, Tone M., \& Rygge, Johan (2009). Det kvalitative forskningsintervju. Oslo: Gyldendal.

Leithwood, Kenneth \& Jantzi, Doris (2005). A review of transformational school leadership research 996-2005. Leadership and policy in schools, 4(3), 177-199. DOI: $10.1080 / 15700760500244769$

Leithwood, Kenneth, Mascall, Blair \& Strauss, Tiiu (red.) (2009). Distributed leadership according to the evidence. London: Routledge.

Lewis, Catherine (2002). Lesson study: A handbook of teacher-led instructional change. Philadelphia: Research for Better Schools, Inc.

Lewis, Catherine, Perry, Rebecca, \& Murata, Aki (2006). How should research contribute to instructional improvement? The case of lesson study. Educational Researcher, 35(3), 3-14. DOI: $10.3102 / 0013189 \times 035003003$

Malterud, Kirsti (2017). Kvalitative forskningsmetoder for medisin og helsefag. Oslo: Universitetsforlaget. 
Makinae, Naomichi (2010). The origin of lesson study in Japan. I: Y. Shimizu, Y. Sekiguchi \& K. Hino (Ed.) In search of excellence in mathematics education 2, 140-147. Tokyo: ICMI.

Munthe, Elaine, Helgevold, Nina, \& Bjuland, Raymond (2015). Lesson Study i utdanning og praksis. Oslo: Cappelen Damm.

Møller, Jorunn \& Ottesen, Eli (Ed.) (2011). Rektor som leder og sjef-om styring, ledelse og kunnskapsutvikling i skolen. Oslo: Universitetsforlaget.

Northouse, Peter G. \& Lee, Marie (2016). Leadership case studies in education. Sage Publications.

Northouse, Peter G. (2016). Leadership: Theory and practice (7th edition). Sage publications.

Robinson, Naomi \& Leikin, Roza (2012). One teacher, two lessons: The lesson study process. International Journal of Science and Mathematics Education, 10(1), 139-161. DOI: 10.1007/s10763-011-9282-3

Robinson, Viviane, Hohepa, Margie \& Lloyd, Claire (2009). School leadership and student outcomes: Identifying what works and why [BES]. Auckland: University of Auckland.

Ronda, Erlina R. (2013). Scaffolding teacher learning through lesson study. In S. A. Ulep, M. B. Ferido, R. L. Reyes \& A. E. Punzalan (Ed.) Lesson Study: Planning together, learning together, 195-216. Quezon City: UPNISMED.

Saito, Eisuke \& Sato, Masaaki (2012). Lesson study as an instrument for school reform: A case of Japanese practices. Management in Education, 26 (4), 181-186. DOI: $10.1177 / 0892020612445101$

Spillane, James P (2006). Distributed leadership. San Francisco, CA: Jossey-Bass.

Spillane, James P (2009). Managing to Lead: Reframing School Leadership and Management. Phi Delta Kappan Magazine, 91(3), 70-73. DOI: 10.1177/003172170909100315

Takahashi, Akihiko (2000). Current Trends and Issues in Lesson Study in Japan and the United States, Journal of Japan Society of Mathematical Education, 82 (12), 15-21.

Cheung, Wai M. \& Wong, Wing Y. (2014). Does lesson study work? A systematic review on the effects of lesson study and learning study on teachers and students. International Journal for Lesson and Learning Studies, 3(2), 137-149. DOI: 10.1108/IJLLS-05-2013-0024 
Wiburg, Karin, \& Brown, Susan (2007). Lesson study communities. California: Corwin Press.Wilkinson,

Jane \& Bristol, Jane (Ed.) (2018). Educational leadership as a culturally-constructed practice: new directions and possibilities. New York: Routledge.

Xu, Haiyan \& Pedder, David (2015). Lesson Study: An international review of the research. In P. Dudley (Ed.) Lesson Study: Professional learning for our time, 29-58. 